\title{
TABOR PAMIĘCI ROMÓW JAKO PRZYKŁAD PROMOWANIA WIEDZY O ROMACH PRZEZ MUZEUM ETNOGRAFICZNE W TARNOWIE
}

\author{
ROMA CARAVAN MEMORIAL AS AN EXAMPLE \\ OF PROMOTION OF KNOWLEDGE ABOUT ROMA \\ BY THE ETHNOGRAPHIC MUSEUM IN TARNÓW
}

\begin{abstract}
The first Roma Caravan Memorial set off from outside the Ethnographic Museum in Tarnów in 1996. It was organised by Adam Bartosz, an expert on Roma culture, history and language, and Adam Andrasz, the president of the Association of Roma in Tarnów.

The Caravan is to commemorate Roma Holocaust. Members of the Roma community can thus learn about the history of extermination from local priests and authors of historical publications. Participants of the Caravan visit the following places of martyrdom: Żabno where possibly 49 of German and 12 of Hungarian Romas were shot by the Nazis in summer 1943), the grave in Borzęcin Dolny where anonymous 28 Romas, killed in the nearby forests, were buried, and Szczurowa where Germans murdered almost an entire Roma settlement of 93 people; the victims were buried in the local cemetery; it is probably the biggest grave of Roma people on the present territory of Poland.

The Caravan Memorial is a project that integrates the Roma and the local community, also friendly villagers, journalists and sometimes passers-by join it.
\end{abstract}

Key words: Roma Caravan Memorial; Ethnographic Museum in Tarnów; Roma Holocaust

This is an Open Access article distributed under the terms of the Creative Commons Attribution 3.0 PL License (creativecommons.org/licenses/by/3.0/pl/), which permits redistribution, commercial and non-commercial, provided that the article is properly cited. (C) The Author(s) 2014.

Publisher: Institute of Slavic Studies PAS [Wydawca: Instytut Slawistyki PAN] 
Pierwszy „Cygański Tabor Pamięci Romów”, który później nazwany został „Międzynarodowym Taborem Pamięci Romów", wyruszył sprzed dziedzińca tarnowskiego Muzeum Etnograficznego w lipcu 1996 roku. Jedną z głównych idei, która przyświecała organizatorom „Taboru” było upamiętnienie zagłady Romów, którym podobnie jak Żydom naziści odmówili prawa do życia i skazali na całkowitą eksterminację. Tabor jest swego rodzaju „pielgrzymką” upamiętniającą kaźń Romów, jak i oddaniem pomordowanym hołdu w miejscu ich wiecznego spoczynku. "Tabor Pamięci Romów" stanowi istotny element dziedzictwa kulturowego Romów zamieszkujących ziemie polskie. Sięganie do tego dziedzictwa, nawiązywanie do niego i ukazywanie w jak najszerszym zakresie niewątpliwie przyczyniać się będzie do głębszego poznania kultury romskiej.

Stowa k luczow e: Tabor Pamięci Romów; dziedzictwo kulturowe Romów; Holocaust

$\mathrm{P}$ ierwszy "Cygański Tabor Pamięci Romów", który później nazwany został "Międzynarodowym Taborem Pamięci Romów", wyruszył sprzed dziedzińca tarnowskiego Muzeum Etnograficznego w lipcu 1996 roku, a więc 32 lata po tym, jak władze PRL przystąpity do realizacji polityki zmierzającej do osiedlenia Romów w Polsce. Wprawdzie nie zabroniono Romom wędrowania, ale zmuszano ich do porzucenia dotychczasowego trybu życia poprzez stosowanie kar za takie przewinienia jak jazdę wozem bez uprawnień, nieposyłanie dzieci do szkół czy brak stałego zameldowania. Powyższe działania miały w konsekwencji doprowadzić do ich ostatecznego osiedlenia (Bartosz, 2004, s. 150).

Pomystodawcami Taboru byli Adam Bartosz i Adam Andrasz, prezes Stowarzyszenia Romów w Tarnowie.

Trwającej cztery dni wędrówce towarzyszy duże zainteresowanie mediów jak i miejscowej ludności oraz sympatyków i badaczy kultury romskiej. Można nawet zaryzykować stwierdzenie, iż w ostatnich latach większość uczestników Taboru stanowią gadziowie, zaś maleje liczba Romów. W takim tonie utrzymana jest m.in. wypowiedź Roma, jednego z uczestników „Taboru”, który w ten sposób skomentował wspomniane wyżej zjawisko:

Byłem pierwszy raz w 2000 roku. To jest 12 lat temu. To tyle. Na drugi rok ja przywiozłem taką grupę ludzi, że Bartosz był zaskoczony. A teraz można powiedzieć, co roku to jest mniej Romów, a więcej gadziów. Są studenci z Krakowa, którzy chcą poznać korzenie Romów. Owszem ja jestem za tym - niech nasza kultura się rozszerza, ale tych Romów trzeba, zwłaszcza młodzież, taką reklamę wystawić. - Zapraszamy (Drużyńska, 2012).

Jedną z głównych idei, która przyświecała organizatorom Taboru, było upamiętnienie zagłady Romów, którym podobnie jak Żydom naziści odmówili prawa do życia i skazali na całkowitą eksterminację (Bartosz, 2003, s. 11). Należy podkreślić, iż Romowie, którym udało się przeżyć zagładę, nie byli świadomi ogromu krzywd, jaki dotknęły ich naród. Tragedia, jaka ich dotknęła, była przez nich postrzegana nie w skali całej społeczności, ale ograniczała się jedynie do losów poszczególnych rodzin czy taborów. Niewątpliwie na takie postrzeganie zagłady wpływ miały doświadczenia romskie ubiegłych wieków, które powodowały u nich przeświadczenie, że jest to kolejny etap prześladowań, tyle tylko, że znacznie okrutniejszy od poprzednich (Bartosz, 2010, ss. 5-6). 
Ponadto istotne znaczenie miał również fakt, iż Romowie byli grupą, która nie posiadała swoich przedstawicieli, którzy by o losie Romów zgotowanym im przez nazistów mówili na forum publicznym czy walczyli o zadośćuczynienie za doznane krzywdy (Bartosz, 2003, s. 7).

Można zaryzykować stwierdzenie, że dzięki takim projektom jak Tabor i jego uczestnikom odwiedzającym miejsca martyrologii romskiej, pamięć o pomordowanych jest nadal żywa, a nawet pogłębia się i jest jednym z elementów budowy narodowej tożsamości Romów (Bartosz, 2003, s. 11). Służy temu również eksponowanie podczas wędrówki takich symboli romskich jak flaga czy hymn.

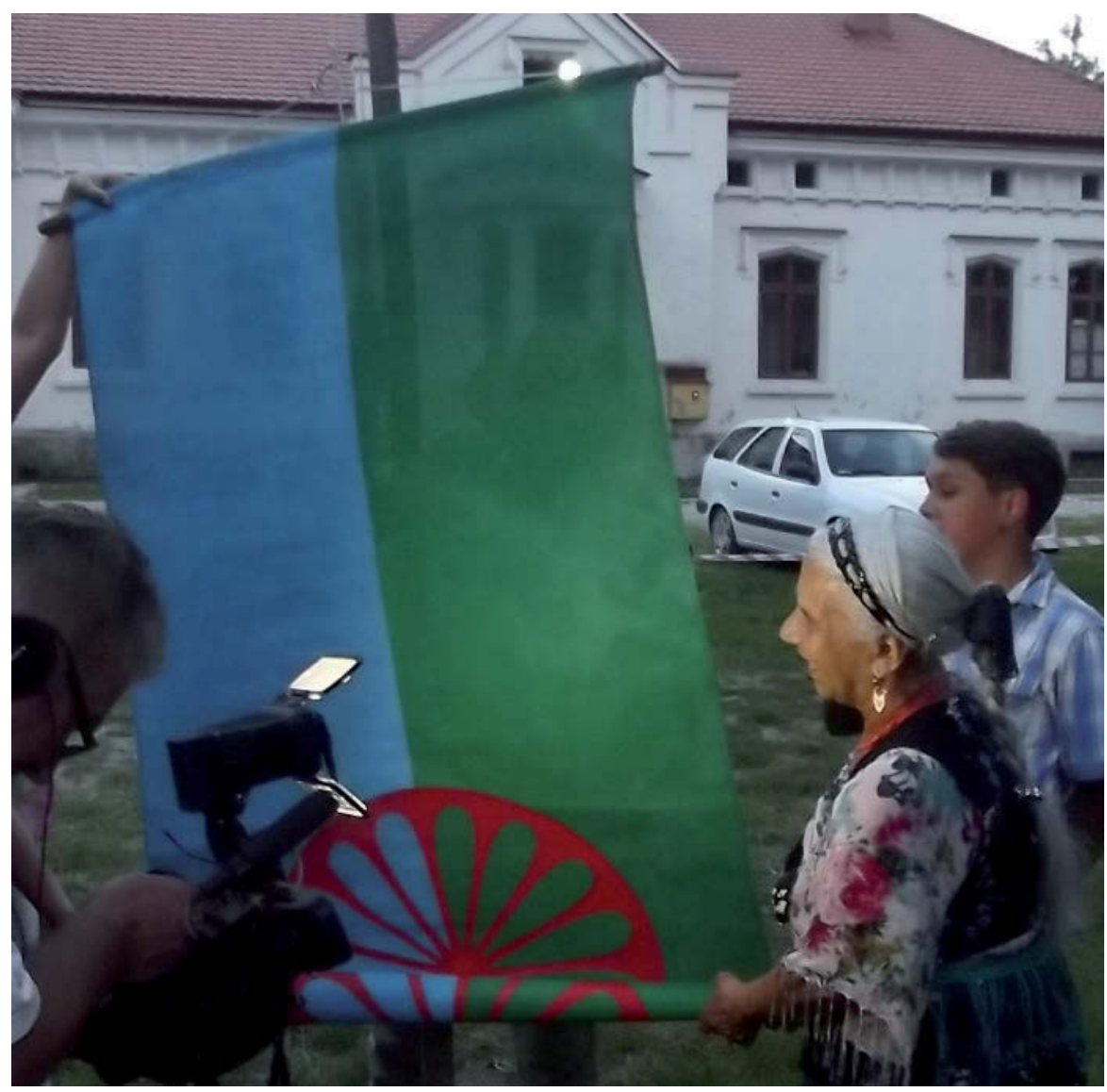

Zdjęcie 1. Wciąganie flagi romskiej na maszt Źr ód o: Archiwum autorki, Szczurowa 2013.

Na uwage zasługuje odwołanie się organizatorów do pozytywnego stereotypu Roma - wiecznego wędrowcy, kochającego taniec, śpiew i otaczającą go przyrodę. Utrwalenie romantycznego wizerunku ma służyć zmianie negatywnego obrazu Roma - włóczęgi, złodzieja, brudasa i oszusta, trudniącego się magią (Mróz, 1992, ss. 159-160). 


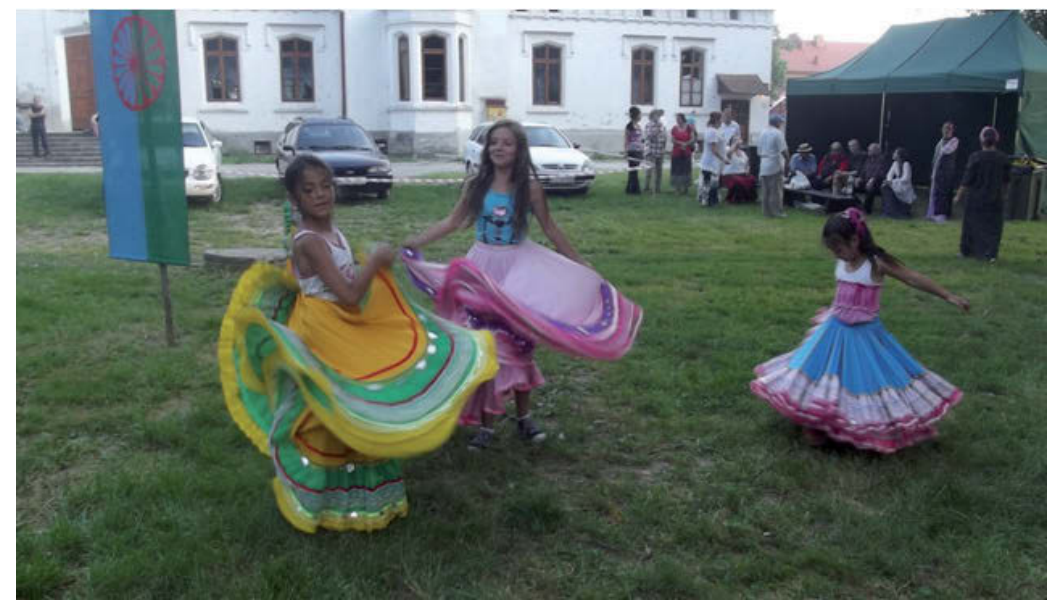

Zdjęcie 2. Tańczące dzieci romskie

Źródło: Archiwum autorki, Szczurowa, 2013.

Ponadto nieoceniona wydaje się wartość projektu, jeżeli chodzi o edukację historyczną i kulturalną dzieci i młodzieży romskiej (Bartosz, 2003, s. 11). Z przekazywanych informacji korzystamy także "my” gadziowie, często nie rozumiejący, ale jednak krytykujący specyficzne elementy kultury romskiej. Jako przykład można tutaj podać wiarę Romów, iż zmarli są „fizycznie” obecni w grobie, a co za tym idzie -- odczuwają potrzebę picia i jedzenia. Wyrazem tego przekonania jest palenie papierosów czy polewanie grobów wódką. Obecnie jesteśmy świadkami, jak ten zwyczaj powoli zanika, kłóci się bowiem on z tradycją chrześcijańską; dla wielu gadziów jest oznaką bezczeszczenia grobu i okazywaniem braku szacunku dla innych ludzi znajdujących się na grobach bliskich. Sami Romowie w ten sposób komentują powyższe zjawisko: „Pije się wódkę na grobie zmarłego, ale teraz już nie, bo Polacy się gniewają, że Cyganie orgie na cmentarzach robią, że piją i śpiewają" (Lubecka, 2005, ss. 170-171).

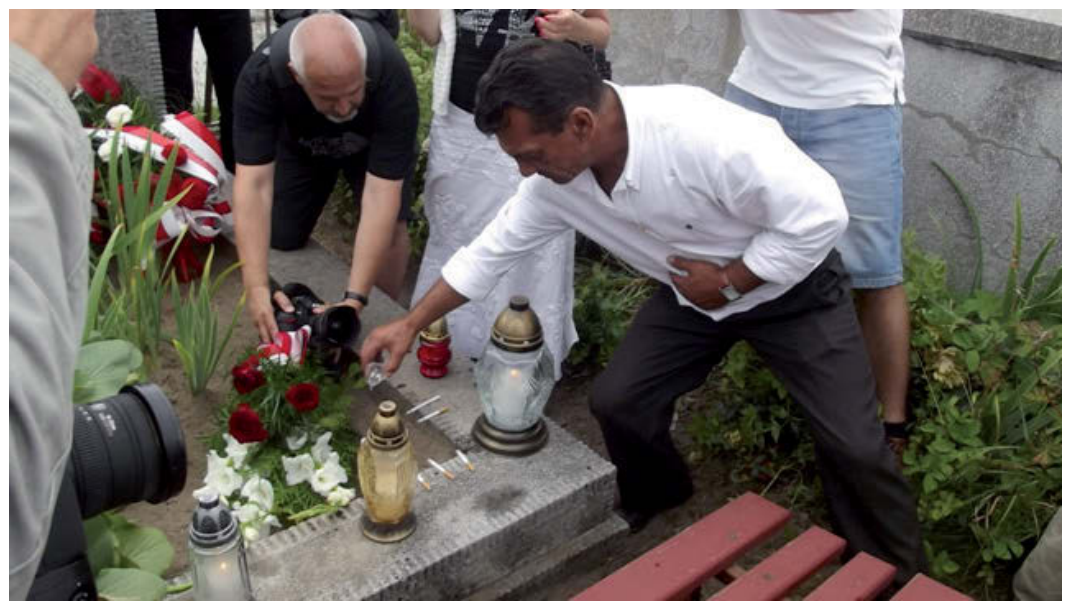

Zdjęcie 3. Ceremonialne ulewanie wódki za dusze zmarłych Źr ód o: Archiwum autorki, Bielcza 2013. 
W tym miejscu należy wspomnieć, iż sami Romowie nie zajmują jednolitego stanowiska co do sposobu upamiętniania ich zagłady. Mowa tu o oburzeniu niektórych krewnych Romów zamordowanych w Szczurowej, którzy uważają, iż występy artystyczne, wesoła atmosfera czy spożywanie alkoholu nijak się mają do powagi miejsca (Kapralski, 2012, ss. 338-339). Świadectwem tego są słowa Krystyny Gil, która ocalała z tragedii, jaka dotknęła Romów w Szczurowej, a mianowicie: „Oddać hołd, proszę bardzo: w skupieniu, ciszy. Ale robić festiwal ze śpiewami, tańcami, piciem wódki?! Czy tak każe Romani pen, święte prawo Romów?” („Tabor nas dzieli”, 1998, s. 14).

Nieco inaczej wypowiada się ksiądz Stanisław Opocki, krajowy duszpasterz Romów, który

nie znajduje w "Taborze pamięci” nic niestosownego: „Przecież modlą się na cmentarzu, a grają w parku. Zawsze proszę, żeby zachowali powściągliwość od alkoholu. Myślę, że gdyby działo się tam coś grzesznego, na pewno powiedziałby mi o tym miejscowy proboszcz" ("Tabor nas dzieli", 1998, s. 14).

Ostatnie edycje Taboru pokazały, iż konflikt udało się załagodzić, o czym świadczy obecność Krystyny Gil chociażby na XIV Międzynarodowym Taborze Pamięci Romów.

Godna podkreślenia jest próba integrowania Romów poprzez odwołanie się do mitu wędrówki, który jest bliski dla Romów prowadzących koczowniczy tryb życia, zaś obcy dla Romów Karpackich, od wieków osiadłych. Służy temu wykorzystanie podczas wędrówki po ziemi tarnowskiej starych romskich wozów z muzealnej kolekcji.

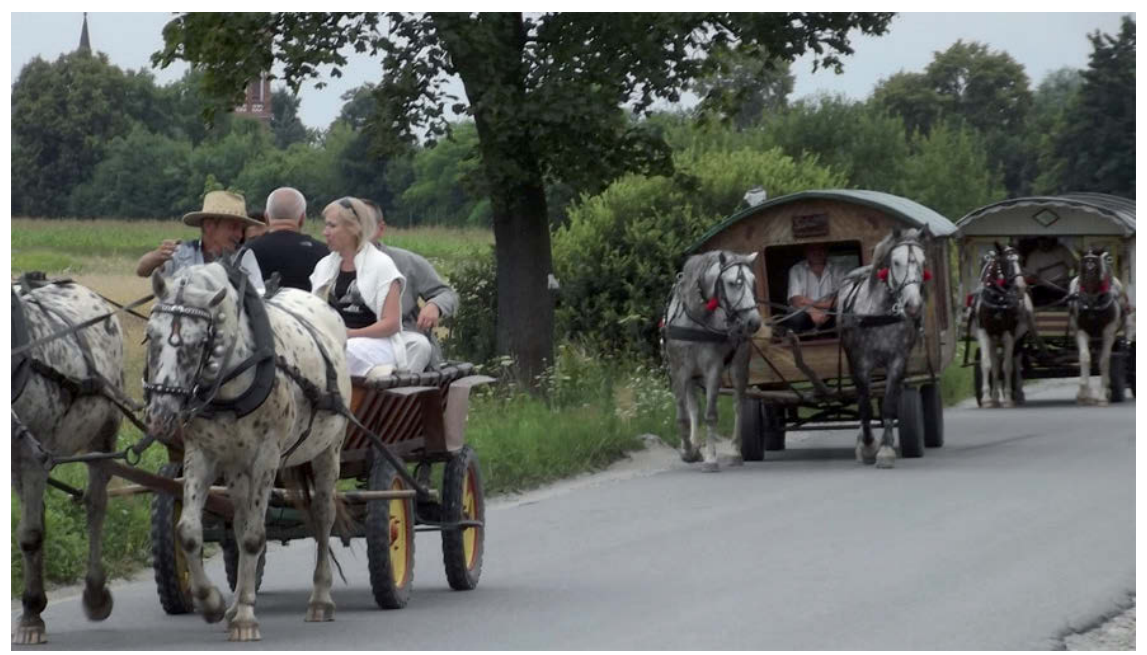

Zdjęcie 4. Przyjazd uczestników Taboru do Bielczy

Źr ód o: Archiwum autorki, Bielcza 2013.

Jak zostało to już wcześniej wspomniane, Tabor jest swego rodzaju „pielgrzymką" upamiętniającą miejsca kaźni Romów, jak i oddaniem pomordowanym hołdu w miejscach ich wiecznego spoczynku. Warto w tym miejscu zaznaczyć, iż nie ma stałej, co roku powtarzającej się trasy taboru, na co niewątpliwie wpływ ma odkrywanie nowych miejsc zagłady romskiej (Kapralski, 2012, s. 332). Ponadto organizatorzy wybierają trase tak, aby przebiegała jak najbardziej atrakcyjnymi drogami, ale też była wygodna zarówno dla koni, ciągnących wozy, jak i uczestników. 


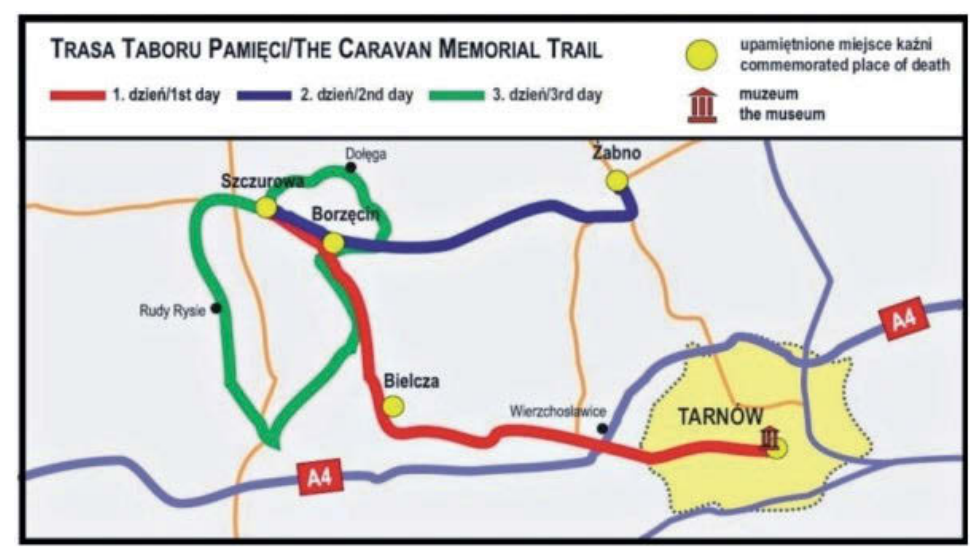

Mapa 1. Trasa XIV Międzynarodowego Taboru Pamięci Romów

Źr ó d to: http://www.muzeum.tarnow.pl/wydarzenia.php?id=101 („XIV Międzynarodowy Tabor Pamięci Romów”, 2013)

Wędrówka Taboru rozpoczyna się na dziedzińcu Muzeum Etnograficznego w Tarnowie, gdzie uczestnicy otrzymują błogosławieństwo z rąk księdza Stanisława Opockiego. Warto podkreślić, iż nie jest to jedyny moment odwołania się do religii, obecność księdza i wspólną modlitwę można bowiem zaobserwować w każdym odwiedzanym przez uczestników wędrówki miejscu.

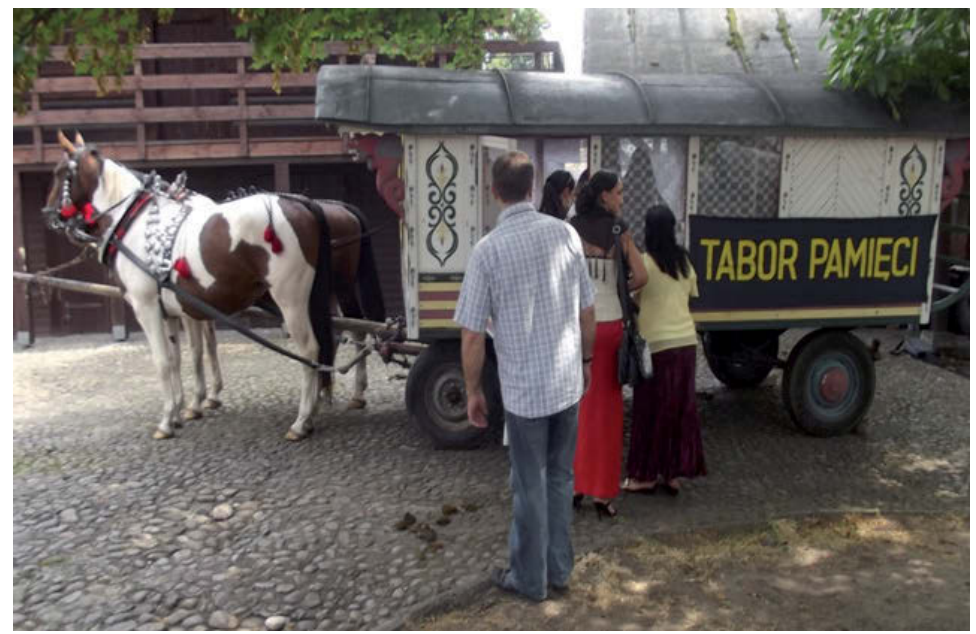

Zdjęcie 5. Przygotowania do wędrówki

Żr ód o: Archiwum autorki, Tarnów 2013.

Następnie barwny korowód wozów i samochodów dociera na Rynek, aby tutaj złożyć kwiaty pod tablicą upamiętniającą śmierć tarnowskich Żydów w czerwcu 1942 roku (Bartosz, 2003, ss. 10-11). Ponadto, uczestnicy Taboru zatrzymują się przy Pomniku Ofiar Oświęcimia, znajdującym się w miejscu, z którego 14 czerwca 1940 roku odbył się pierwszy transport do obozu Auschwitz grupy 728 mężczyzn, którzy stali się tym samym pierwszymi więźniami obozu oświęcimskiego (Bartosz, 2003, s. 15). 
Jak widać, w czasie wędrówki Romowie nie tylko odwiedzają miejsca martyrologii romskiej, ale solidaryzują się z tragedią, jaka spotkała Żydów i Polaków.

Ważnym momentem dla zgromadzonych Romów jest odwiedzenie cmentarza w dzielnicy Krzyż, gdyż znajdują się tutaj groby ich bliskich. Modlitwie za dusze zmarłych towarzyszą wspomnienia, przybierające czasem formę krótkich „prywatnych” przemówień (Kapralski, 2012, s. 332).

Pisząc o wędrówce Taboru po miejscach martyrologii romskiej, koniecznie trzeba wspomnieć o Żabnie, w którym znajduje się mogiła pomordowanych, bezimiennych Romów. Uczestnicy Taboru modlą się za spoczywającą tutaj prawdopodobnie grupę 49 Romów niemieckich, którzy deportowani zostali w 1940 roku na tereny okupowanej Polski, a następnie w lipcu 1943 roku rozstrzelani. Warto podkreślić, że w tej samej mogile pochowano później kolejne 12 osób, tym razem z grupy Romów węgierskich, zamordowanych w Biskupicach Radłowskich („Uroczystość odsłonięcia nowego pomnika na mogile Romów”, 2012).

Uroczystości w Żabnie nabierają szczególnego charakteru, bowiem tak jak zostało już wcześniej wspomniane, pochowani zostali tu przedstawiciele romscy z Niemiec i Węgier, co jest niezwykle istotne w ukazaniu wspólnego losu Romów podczas II wojny światowej (Kapralski, 2012, s. 333).

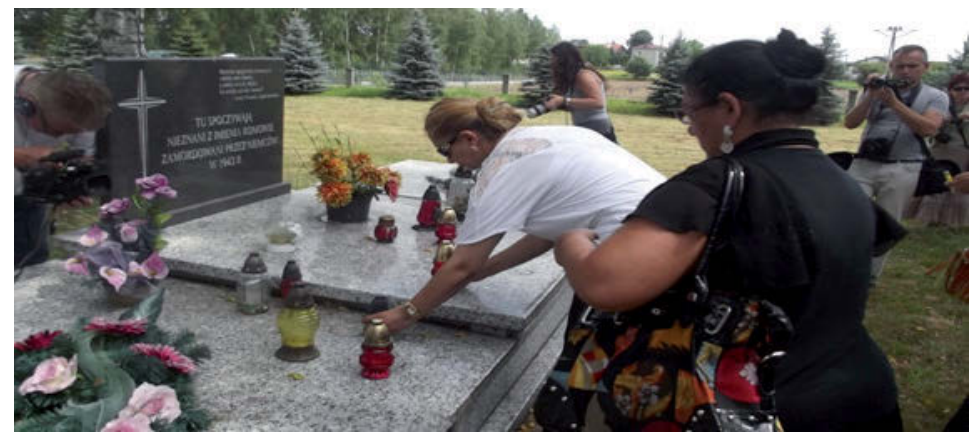

Zdjęcie 6. Uczestnicy Taboru na cmentarzu w Żabnem

Źr ó d to:Archiwum autorki, Żabno 2013.

Należy zaznaczyć, iż obecny wygląd mogiły w Żabnie jest zasługą Muzeum Okręgowego, które uzyskało z Ministerstwa Administracji i Cyfryzacji dofinansowanie na wykonanie płyty nagrobnej oraz tablicy upamiętniającej pomordowanych Romów.

Istotnym punktem na szlaku wędrówki Taboru po miejscach zagłady romskiej jest Bielcza w powiecie brzeskim. Tu zamordowano co najmniej 19 osób, w większości kobiety i dzieci, głównie członków rodu Kwieków, ze szczepu Kelderaszy. Byli oni związani z tym terenem od początku XX wieku, tutaj przeczekiwali zimę w wynajętych domach, a co za tym idzie często podawali jako miejsce pobytu czy nawet swojego pochodzenia właśnie ten region. Tak też było jesienią 1941 roku, kiedy Niemcy nakazali wójtowi Bielczy przyjąć i zameldować grupę składającą się z 32 osób, która jako miejsce swojego pochodzenia podała Bielczę. Zamieszkali we wskazanym im domu i stodole w przysiółku Biedacz. Momentem przełomowym był dla nich lipiec 1942 roku, kiedy to zostali oskarżeni o kradzież, a następnie wymordowani. Ocalała tylko grupa mężczyzn, która w owym czasie nie była obecna na miejscu tragedii. Zgodnie z rozkazem niemieckim zostali oni zakopani w miejscu mordu, zaś ich zwłoki ekshumowano w 1958 roku i przeniesiono na miejscowy cmentarz (Bartosz, 2010, ss. 27-28). 


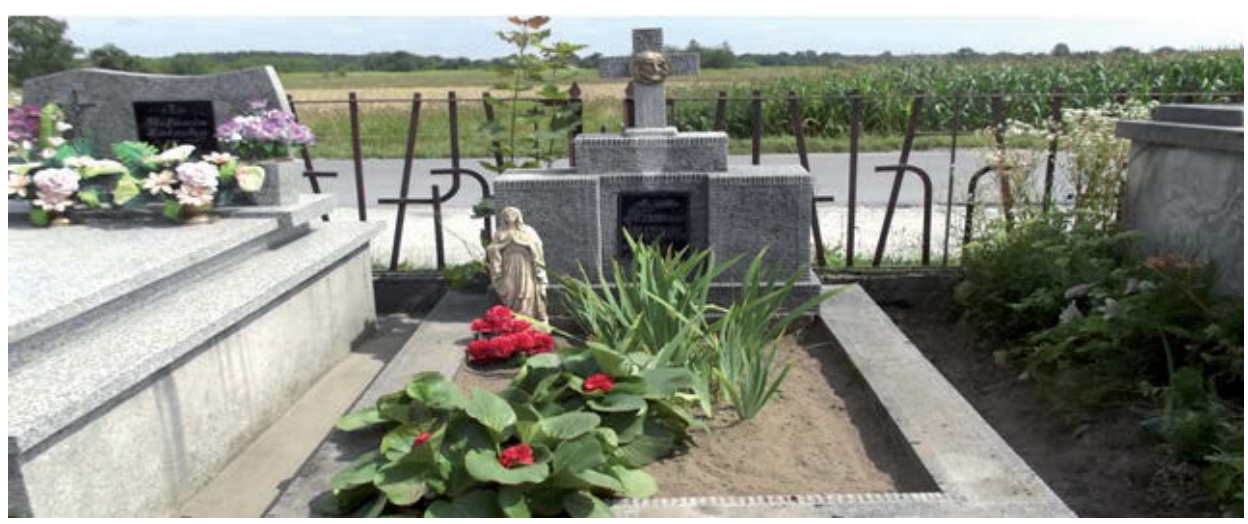

Zdjęcie 7. Zbiorowy grób Cyganów rozstrzelanych w Bielczy w 1942 roku Źr ó d ł o: Archiwum autorki, Bielcza 2013.

Analizując miejsca odwiedzane przez uczestników Taboru, nie sposób pominąć Borzęcina Dolnego, gdyż właśnie tutaj, w okolicy Wał Rudy, doszło do kolejnego mordu na Romach. Tragedia rozegrała się w lipcu 1942 roku, kiedy żandarmi niemieccy zatrzymali w okolicy Wał Rudy grupę składającą się z 29 Romów, w skład której wchodziło 3 mężczyzn, 5 kobiet oraz 21 dzieci. Zatrzymanych Romów umieszczono na wozach, powożonych przez miejscowych chłopów. Pierwotnie złapanych Romów miano zastrzelić nad rzeką Kisieliną, między Wolą Radłowską a Wał Rudą, jednak błagania miejscowej ludności, która nie chciała, aby do tak okrutnej zbrodni doszło w pobliżu wioski, zmieniły wcześniejsze plany. Niemcy wywieźli ofiary w kierunku Borzęcina i w lesie pozbawili je życia (Bartosz, 2010, ss. 30-31).

Warto przytoczyć relacje świadków powyższego zdarzenia. W taki oto sposób tragedię Romów opisał Józef Siudut:

Kazali się im wszystkim kłaść głowo do ziemi. Jak im kazali się kłaść to wszyscy krzyczeli. Jeden się nie położył, uciekał. Niemiec z pistoletu dwa strzały oddał, ale go nie trafit. Polecił strzelać granatowym policjantom. Dwóch policjantów strzelało do niego, ale go nie trafili. Uciekł. Wszystkim kazali się pokłaść na ziemi. Grubszy Niemiec szedł i po kolei strzelat. Wołali po swojemu.

Myśmy stali z boku, widziałem jak podchodził do każdego. Zabił trzech dorosłych mężczyzn, pięć kobiet i dwadzieścia jeden dzieci. Te dzieci to miały taki różny wiek. Najmłodsze matka na ręce trzymała, pierś ssało. Mogło mieć jakieś sześć miesięcy. Matka jego gruba była, mogła mieć 45 lat. Reszta to były takie chudziny. Te dzieci takie małe, może które miało 12 lat. Wszystko wystrzelali (...) (Kołodziejski, 2008b, s. 11).

Na uwagę zasługuje również relacja Zofii Kilian, która była zaledwie 6-letnim dzieckiem w chwili zbrodni dokonanej na Romach. Oto jak pamięta ona całe to zdarzenie:

Cygani przywiezieni byli 2 wozami drabiniastymi o kołach drewnianych. W zaprzęgu była po 2 konie maści "kasztan”. Chłopi musieli wieźć ich swoimi wozami, bo wozy Cyganów były inne. Za nimi, z tyłu w dwukonnej bryczce jechało 2 Niemców z bronią w ręku. Droga była wtedy piaszczysta i oni jechali wolno. Cyganie byli gęsto usadowieni na wozach "głowa przy głowie". Widziałam, jak jechali od strony Szczurowej. Skąd byli tego nie wiem. Nie widziałam nikogo, policjantów nie było. Niemcy mieli ręczne karabiny. Po zejściu z wozów ustawili ich przed górą żóttego piasku bezpośrednio przylegającą do drogi. Działo się to po lewej stronie drogi jadąc w kierunku Wał-Rudy, pomiędzy zabudowaniami Wojciecha Klisiewicza i Leśniczówką w której mieszkali Rębacze. 
Dochodzili do każdego i strzelali. Słyszałam; pisk, krzyk, płacz, szloch "jujk" dosłownie takie wycie. No mówię, to nie do przeżycia. Nie rozumiałam ich słów. Trwało to z pół godziny. Strzelali w dwóch i nie było to takie "trr" tylko pach-pach-pach. Widziałam: mężczyzn, dzieci i kobiety. Niemcy w zielonych mundurach byli obróceni do nas plecami. Widziałyśmy jak rozstrzeliwani padali, kobiety trzymały na ręku dzieci. Dzieci były takie małe i takie większe (Kołodziejski, 2008a, s. 32).

Szczątki zamordowanych Romów zostały ekshumowane w 1959 roku i pochowane w zbiorowej mogile na cmentarzu parafialnym w Borzęcinie Dolnym. W upamiętnieniu miejsca mordu dużą rolę odegrali organizatorzy Taboru, z Adamem Bartoszem na czele. Podczas XII Międzynarodowego Taboru Pamięci Romów odsłonięto Pomnik Pamięci o Zagładzie Romów w Borzęcinie Dolnym. Zaprojektowany on został przez Małgorzatę MirgęTas, romską artystkę i absolwentkę krakowskiej Akademii Sztuk Pięknych (Gancarz, 2011, ss. 267-270).

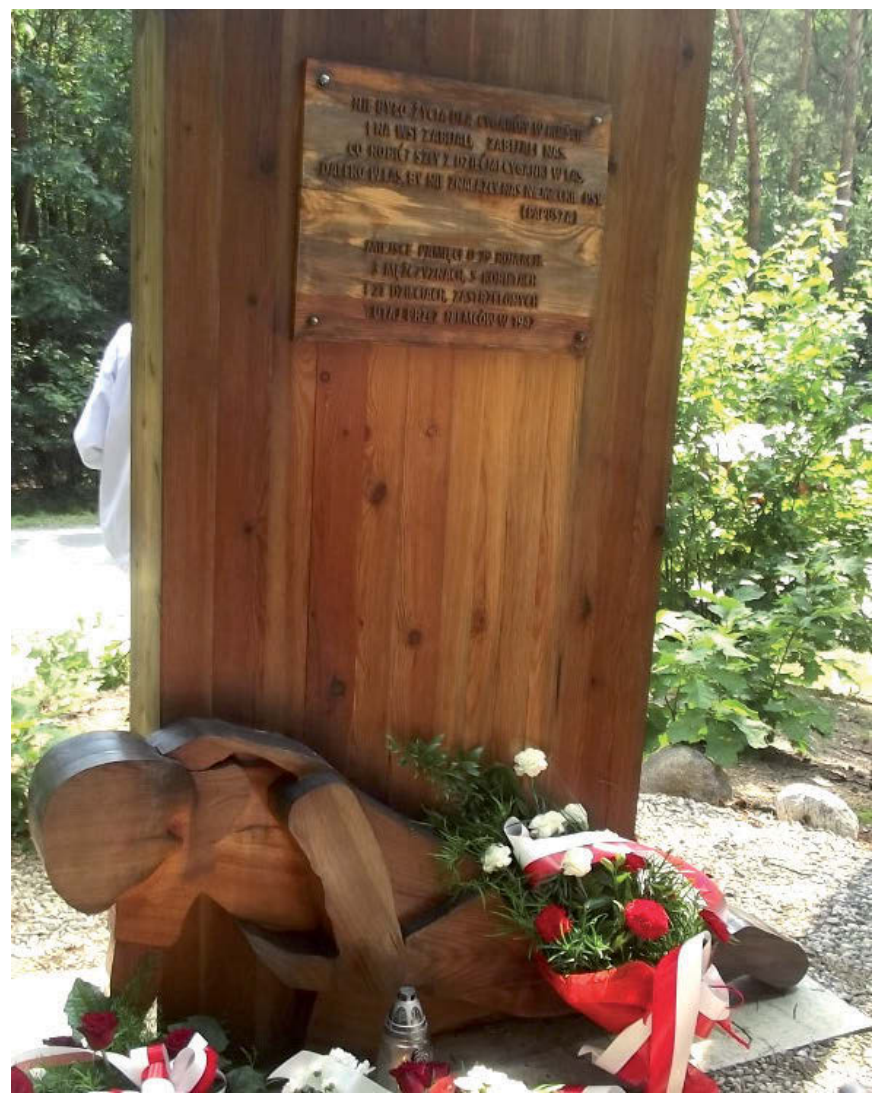

Zdjęcie 8. Pomnik Pamięci o Zagładzie Romów w Borzęcinie Dolnym

Źr ó d to: Archiwum autorki, Borzęcin Dolny, 2013.

Warto zwrócić uwagę na 29 kamieni otaczających pomnik, z których każdy symbolizuje jedno życie ludzkie. Ponadto na tablicy umieszczony został fragment pieśni romskiej poetki Papuszy, mówiący o ludzkim wymiarze tragedii, jaka dotknęła Romów (zob. zdjęcie 9 poniżej). 


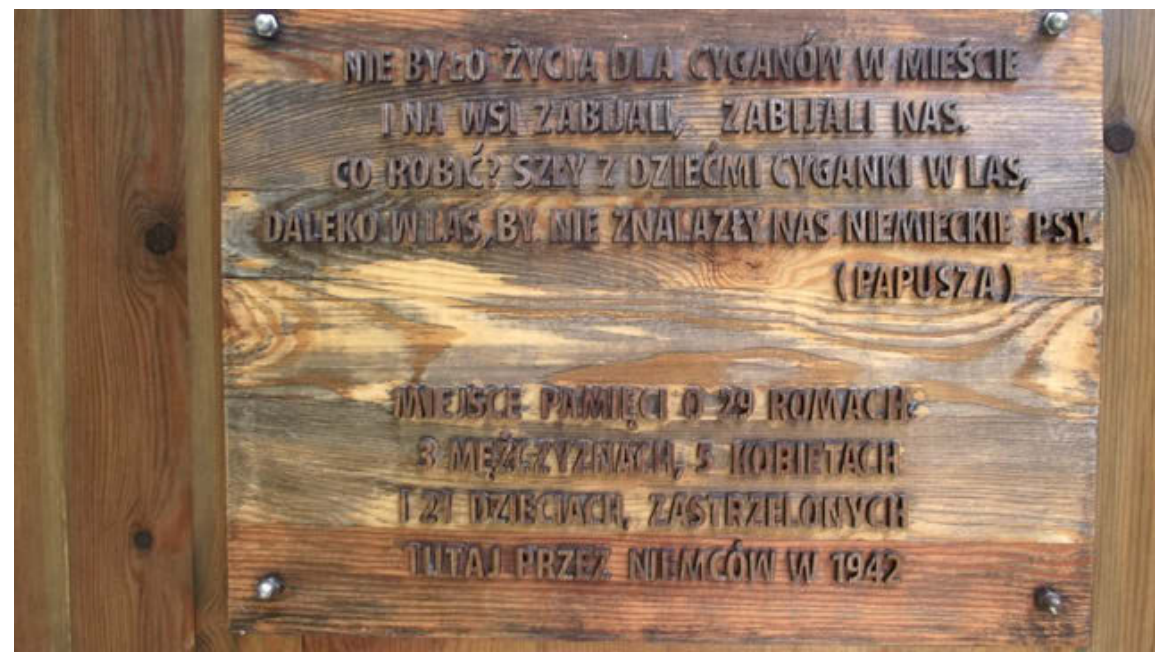

Zdjęcie 9. Tablica na Pomniku Pamięci o Zagładzie Romów

Źr ó d † o: Archiwum autorki, Borzęcin Dolny 2013.

Najważniejszym jednak celem kilkudniowej wędrówki jest miejscowość Szczurowa, gdyż tu znajduje się najprawdopodobniej największa w Polsce zbiorowa mogiła Romów, w której spoczywają aż 93 osoby zamordowane 3 sierpnia 1943 roku (Bartosz, 2012, s. 21). Niemcy zabili wtedy prawie całą społeczność romską żyjącą na skraju wsi. Jedną z osób, której udało się ocalić z tragedii, a która jest obecnie jedynym żyjącym świadkiem zbrodni, jest Krystyna Gil, z domu Ciuroń, mieszkająca obecnie w Nowej Hucie. O skali tragedii, jaka ją dotknęła, może świadczyć fakt, iż jedynie ona i jej babcia uszły z życiem, zaś pozostali członkowie rodziny, aż 42 osoby, zostały rozstrzelane. Krystyna Gil mimo iż była wtedy małym dzieckiem, mającym zaledwie 5 lat, pamięta ten dzień bardzo dokładnie, a na jego wspomnienie nadal drży jej głos. Z przejęciem opowiada, iż jedną z pierwszych ofiar był jej dziadek, który odmówił wyjścia z domu, za co poniósł najwyższą z możliwych kar - stracił życie. Jak twierdzi, już wtedy wszyscy wiedzieli, że spotka ich to samo. Wraz z mamą i 10-letnim bratem znajdowała się na wozie, którego ostatnią drogą miał być cmentarz. Mama wykorzystała okazję i podała ją stojącej obok wozu babci (która była Polką), mówiąc: "Słuchaj mamo, jak zostaniesz, to chociaż ona ci zostanie”. Babcia nie za bardzo chciała ją wziąć, wolała starszego brata, który jednak odmówił, stwierdzając, iż "jak mama ginie, to ja z nią"1.

Szczurowa jest miejscem szczególnym, gdyż właśnie tutaj znajduje się, według Bartosza, pierwszy na świecie pomnik upamiętniający Romów pomordowanych w okresie II wojny światowej (Bartosz, 2010, ss. 33-34). Nie do końca zgadza się z tym stwierdzeniem Kapralski, który powołuje się na tablicę z wyrytym na kamiennym obelisku napisem o następującej treści: „Zbiorowa mogiła 93 mieszkańców Szczurowej zamordowanych przez hitlerowców". Według Kapralskiego treść wprawdzie wskazuje na wydarzenie, które dotyczyło wyłącznie Romów, ale w tekście nie użyto sformułowania „romska zagłada” ani „Romowie” (Kapralski, 2012, s. 333).

Rozmowa autorki z Krystyną Gil podczas powrotu z uroczystości z cmentarza w Szczurowej do obozowiska, 27.07.2013. 


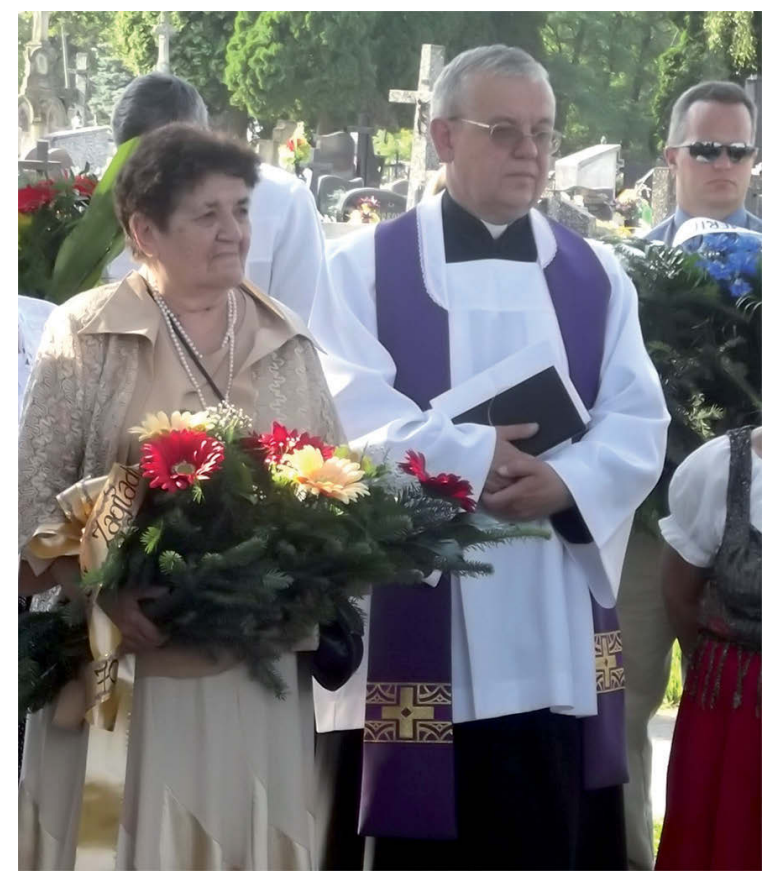

Zdjęcie 10. Krystyna Gil, jedyny żyjący świadek zbrodni na Romach w Szczurowej, oraz ksiądz Stanisław Opocki, krajowy duszpasterz Romów.

Źr ód o: Archiwum autorki, Szczurowa 2013

Według Bartosza taki stan rzeczy mógł być spowodowany bardzo silną identyfikacją mieszkańców Szczurowej z zabitymi Romami, którzy w pierwszej kolejności byli przez nich postrzegani jako współmieszkańcy, a dopiero potem brano pod uwage fakt, iż byli Romami (Bartosz, 2010, ss. 34-35).

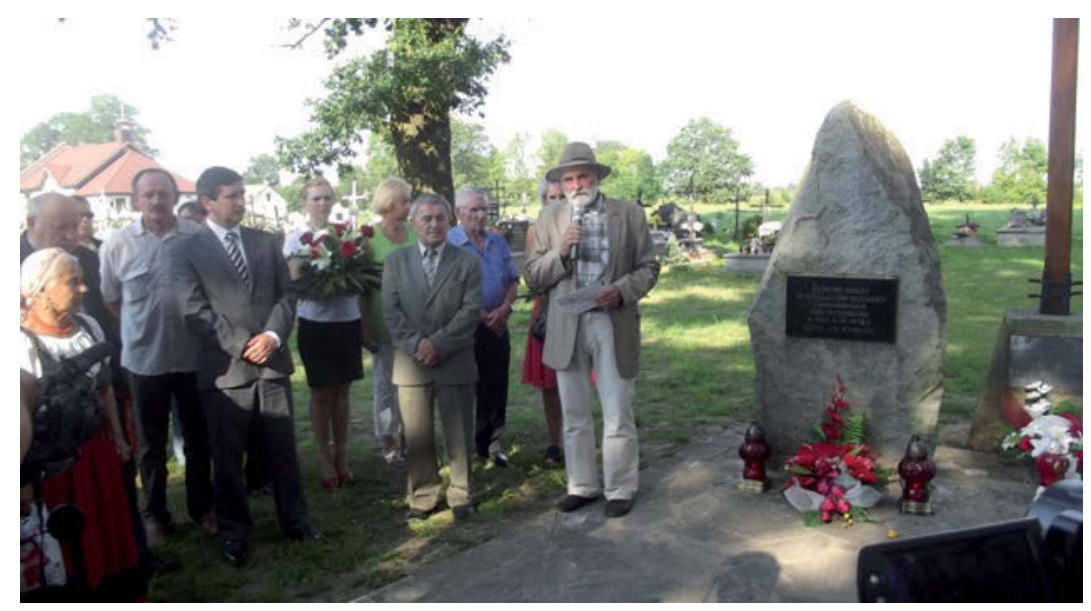

Zdjęcie 11. Uczestnicy XIV Taboru na cmentarzu w Szczurowej Źr ó d o: Archiwum autorki, Szczurowa 2013. 
Obok wspomnianego już kamiennego obelisku w 1993 roku postawiono krzyż wraz z tablicą o następującej treści:

\author{
3 VII 1943-10 VII 1993 \\ W 50-TA ROCZNICE ZAMORDOWANIA \\ 93 CYGANÓW - ROMÓW \\ PODCZAS OKUPACJI HITLEROWSKIEJ \\ HOŁD MODLITEWNY SKŁADAJA \\ MIESZKAŃCY SZCZUROWEJ
}

(Bartosz, 2010, s. 35)

Z perspektywy dnia dzisiejszego można stwierdzić, że "Tabor Pamięci Romów" stanowi istotny element dziedzictwa kulturowego Romów zamieszkujących ziemie polskie. Sięganie do tego dziedzictwa, nawiązywanie do niego i ukazywanie w jak najszerszym zakresie niewątpliwie przyczyniać się będzie do głębszego poznania kultury romskiej i służyć tolerancji, z której na przestrzeni wieków słynęła Polska.

\title{
BIBLIOGRAFIA
}

Bartosz, A. (2003). Tabor Pamięci Romów. Tarnów: Wydawnictwo S-Can.

Bartosz, A. (2004). Nie bój się Cygana [Na dara Romestar]. Sejny: Fundacja Pogranicze.

Bartosz, A. (2010). Matopolski szlak martyrologii Romów. Tarnów: Wydawnictwo S-Can.

Bartosz, A. (2012). Romowie w Polsce: kalendarium 1401-2012. Tarnów: Wydawnictwo S-Can.

Drużyńska, J. (2012). Nawet gdy umrę będe śpiewat. Radio Kraków.

Gancarz, N. (2011). Pierwszy figuralny Pomnik Pamięci o Zagładzie Romów. Studia Romologica, (4), 267-270.

Kapralski, S. (2012). Naród z popiołów: pamięć zagłady a tożsamość Romów. Warszawa: Wydawnictwo Naukowe Scholar.

Kołodziejski, L. (2008a). Ostatni świadek?. Kurier Borzęcki, 2(49), 33. Pobrano 3 stycznia 2014, z http://www.borzecin.pl/images/stories/kurier/kurier\%20borzecki\%20nr\%20 2(49)2008.pdf

Kołodziejski, L. (2008b). Ostatni żyjący świadkowie zbrodni: jak zbudować zdania, gdy z każdego winna tryskać krew?. Kurier Borzecki, 1(48), 11-13. Pobrano 3 stycznia 2014, z http://www.borzecin.pl/images/stories/kurier/kurier\%20borzecki\%20nr\%20 1(48)2008.pdf

Lubecka, A. (2005). Tożsamość kulturowa Bergitka Roma. Kraków: Księgarnia Akademicka. Mróz, L. (1992). Geneza Cyganów i ich kultury. Warszawa: Wydawnictwo Fundacji „Historia pro Futuro".

Tabor nas dzieli. (1998, sierpień 24). Gazeta Wyborcza, s. 14.

Uroczystość odsłonięcia nowego pomnika na mogile Romów. (2012). Pobrano 23 listopada 2013, z http://www.zabno.pl/index.php?news=02779

XIV Międzynarodowy Tabor Pamięci Romów. (2013). Pobrano 23 listopada 2013, z http:// www.muzeum.tarnow.pl/wydarzenia.php?id=101 